\title{
Preliminary study on antimicrobial efficiency of some common chemical substances with a disinfecting character on impression materials used in implant-prosthetic rehabilitation
}

\author{
Gabriel CIOCHINDA ${ }^{1}, \mathrm{MD}$, PhD student, Lorelai Georgeta BILINSCHI², MD, \\ Univ. Assist. Gabriela TANASE ${ }^{1}$, MD, Univ. Assist. Claudia-Camelia BURCEA ${ }^{1}, \mathrm{MD}$, \\ Univ. Assist. Viorel Stefan PERIEANU ${ }^{1}$, MD, Assoc. Prof. Mihai BURLIBASA ${ }^{1}, \mathrm{MD}, \mathrm{PhD}$, \\ Univ. Assist. Magdalena DINA ${ }^{1}$, MD, Univ. Assist. Madalina Violeta PERIEANU ${ }^{1}$, MD, \\ Univ. Assist. Radu COSTEA ${ }^{1}, \mathrm{MD}$, Raluca COSTEA $^{3}, \mathrm{MD}$, Prof. Dana Cristina BODNAR ${ }^{1}, \mathrm{MD}, \mathrm{PhD}$, \\ Assoc. Prof. Liliana BURLIBASA ${ }^{4}, \mathrm{MD}, \mathrm{PhD}$, Lecturer Traian BODNAR ${ }^{1}, \mathrm{MD}$, \\ Univ. Assist. Oana EFTENE ${ }^{1}, \mathrm{MD}$, Assoc. Prof. lleana IONESCU ${ }^{1}, \mathrm{MD}, \mathrm{PhD}$ \\ 1"Carol Davila" University of Medicine and Pharmacy, Bucharest \\ ${ }^{2}$ S.C. LIODENT CLINIQUE S.R.L., Sibiu \\ ${ }^{3}$ S.C. Dentexpert Magic S.R.L. Brasov \\ ${ }^{4}$ Faculty of Biology, University of Bucharest
}

\begin{abstract}
Purpose. Starting from a very recent event on the market of disinfectants, where for many years very diluted disinfectant products were marketed in Romania, the antimicrobial activity being non-existent, we tried, on the basis of simple experiments, to study the antimicrobial efficiency of the active substances of some common products used on impression materials in implant-prosthetic rehabilitation, but also in classical dental prosthetics and in orthodontics and dentofacial orthopedics, products approved and used in the European Union.

Material and method. 7 decontamination and/or disinfectant products were tested for qualitative screening for the sensitivity to different microbial strains as well as for quantitative testing of antimicrobial activity.

Results and discussions. The study results for the two objectives are influenced by the active substances of the tested products.

Conclusions. Decontamination of dental impressions must also become a certainty in implant-prosthetic rehabilitation, in classical dental prosthetics and in orthodontics and dentofacial orthopedics even if this work is disregarded and ignored by many practitioners.
\end{abstract}

Keywords: chemical substances, disinfectant character, active substances, implant-prosthetic rehabilitation

\section{INTRODUCTION}

The present study, although only a preliminary one, attempts, on the basis of simple clinical and microbiological experiments, to determine the antimicrobial effectiveness of some chemical disinfectant substances on standard impression materials, commonly used in implant-prosthetic rehabilitation, in classical dental prosthetics, as well as in orthodontics and dentofacial orthopedics. In fact, we are talking about existing active substances, which are 
present in standardized products, approved and used in the European Union. We did not use the trade names of these products to respect what we could define not only discretion but also professional equidistance, especially since we have chosen a less used medical procedure in implant-prosthetic rehabilitation, namely impressions decontamination, and indications of these substances with disinfecting potential have not always been recommended for this procedure (Table 1).

From our point of view, the decontamination of dental impressions in implant-prosthetic rehabilitation, and in classical dental prosthetics, as well as in orthodontics and dentofacial orthopedics should become mandatory in the technological flow of realization of implant-retained prosthetic restorations of any kind, but also of fixed and mobile classical prosthetic restorations, as well as of orthodontic appliances.

Unfortunately, this procedure is considered by many practitioners in Romania (dental practitioners, dental nurses and dental technicians) as a slowing down and even useless procedure that unnecessarily complicates these technological flows (1-6).

\section{PURPOSE}

The purpose of this study is to test a series of decontamination, disinfection and even cold sterilization products approved and used in the European Union in dentistry, including implant-prosthetic rehabilitation, classical dental prosthetics and orthodontics and dentofacial orthopedics. These products are based on various active substances, their instructions being varied, starting from the decontamination and disinfection of manual and rotary instruments, even dental impressions, antiseptication of the skin and ending with the decontamination and disinfection of the surfaces. The present study can provide only some information on the antimicrobial efficacy of these active substances; the choice indication of the products used may contradict the purpose for which we have used these substances (1-6).

\section{MATERIAL AND METHOD}

To carry out this study, we took into account several decontamination and/or disinfectant products approved and used in the European Union, which are presented in the table below (Table 1). As mentioned above, in order to avoid commercial controversy, we will not specify the names of products used in this study, but we will use the generic name of "disinfectant product".

The used products are based on the following active substances: quaternary ammonium salts (most commonly used), alcohols, peroxides (peracetic acid) and halogenated compounds (sodium hypochlorite). We did not enter products with the glutaraldehyde as active substance, this chemical having a recognized allergenic and carcinogenic potential for users (7-17).

TABLE 1. Substances with antimicrobial potential used in this study

\begin{tabular}{|l|l|l|}
\hline Label & $\begin{array}{l}\text { Active } \\
\text { substance }\end{array}$ & Use \\
\hline $\begin{array}{l}\text { Disinfectant } \\
\text { Product no. 1 }\end{array}$ & Alcohols & $\begin{array}{l}\text { For surfaces } \\
\text { decontamination and } \\
\text { disinfection }\end{array}$ \\
\hline $\begin{array}{l}\text { Disinfectant } \\
\text { Product no. 2 }\end{array}$ & Alcohols & Hands antiseptic \\
\hline $\begin{array}{l}\text { Disinfectant } \\
\text { Product no. 3 }\end{array}$ & Alcohols & $\begin{array}{l}\text { For the decontamination } \\
\text { and disinfection of dental } \\
\text { and medical devices } \\
\text { surfaces }\end{array}$ \\
\hline $\begin{array}{l}\text { Disinfectant } \\
\text { Product no. 4 }\end{array}$ & Peracetic acid & $\begin{array}{l}\text { For high level } \\
\text { disinfection/cold } \\
\text { sterilization of manual } \\
\text { and rotary instruments }\end{array}$ \\
\hline $\begin{array}{l}\text { Disinfectant } \\
\text { Product no. 5 }\end{array}$ & $\begin{array}{l}\text { Quaternary } \\
\text { Ammonium } \\
\text { Salts }\end{array}$ & $\begin{array}{l}\text { Instruments and } \\
\text { dental impression } \\
\text { decontamination }\end{array}$ \\
\hline $\begin{array}{l}\text { Disinfectant } \\
\text { Product no. 6 }\end{array}$ & $\begin{array}{l}\text { Quaternary } \\
\text { Ammonium } \\
\text { Salts }\end{array}$ & $\begin{array}{l}\text { For decontamination and } \\
\text { disinfection of manual } \\
\text { and rotary instruments }\end{array}$ \\
\hline $\begin{array}{l}\text { Disinfectant } \\
\text { Product no. 7 }\end{array}$ & $\begin{array}{l}\text { Sodium } \\
\text { Hypochlorite }\end{array}$ & $\begin{array}{l}\text { Detergent/disinfectant } \\
\text { for pavements }\end{array}$ \\
\hline
\end{tabular}

Two phases were followed, namely:

1. Qualitative screening of susceptibility of different microbial strains to substances with potential anti-infective action.

It was done by a method adapted to the diffusometry method, namely the distribution of the chemical compound in a spot on Muller-Hinton broth seeded with a microbial suspension.

The bacterial inoculum was a suspension in sterile physiological water with a density of 0.5 McFarland. The volume distributed in the spot was $10 \mu \mathrm{l}$ of the test product. After seeding, the plates were allowed to stand at room temperature for adsorption of the solution drop in the medium, after which they were incubated at $37^{\circ} \mathrm{C}$ (with thermostat) with the lid down for 24 hours. The bactericidal effect of the compound (inhibition of bacterial growth) was quantified by the occurrence of an inhibition zone (clear area) around the spot. 
2. Quantitative testing of antimicrobial activity in order to determine quantitative parameters of antimicrobial activity on clinically isolated bacterial strains

Quantitative testing was performed by the serial microdilution method in liquid broth ( $\mathrm{Mu}-$ eller Hinton), using 96-well plates to determine the minimum inhibitory concentration of the MMI (Minimum Inhibitory Concentration), the minimum amount of chemical compound capable of inhibiting the growth of microbial cells. In a volume of $100 \mu \mathrm{l}$ of broth, serial binary dilutions of the stock solution of the compound were made. $100 \mu$ l of liquid broth and $100 \mu$ of chemical compound were pipetted into the first well. From the first well, $100 \mu \mathrm{l}$ was transferred to the second well, the previous procedure was repeated and $100 \mu \mathrm{l}$ was transferred to the third well and thereafter to the last well in which 100 $\mu \mathrm{l}$ was transferred without the addition of the chemical compound. Subsequently, the wells were seeded with $20 \mathrm{ml}$ of microbial suspension 0.5 MacFarland density. Microbial suspensions were carried out in sterile physiological water from 24-hour cultures. At each test, a control microbial culture (a row of wells containing only inoculated growth medium with microbial suspension) and a control of medium sterility were used. After incubating the plates at $37^{\circ} \mathrm{C}$ for 24 hours, optical density was read on the spectrophotometer (wavelength used $620 \mathrm{~nm}$ ). In the growth control well, the medium was cloudy as a result of microbial growth. The sterility control well did not show any bacterial growth, the liquid content remaining clear, transparent. The concentration of chemical compound corresponding to the last well in which culture development was no longer observed was C.M.I. ( $\mu \mathrm{g} /$ $\mathrm{ml}$ ) for the compound.

\section{RESULTS AND DISCUSSIONS}

Following the completion of microbiological studies, it was found that:

For the first stage of the study, the qualitative analysis of antimicrobial activity of these selected products existing in the specialized market was highlighted by obtaining inhibition areas around the substance spot (Fig. 1). Disinfectant Product no. 2 (according to Table 1, with the active substance based on alcohols and with the main indication hands antiseptic) showed the lowest inhibition area, followed by Disinfectant Product no. 4 (according to Table 1, compound based on peracetic acid, being rec- ommended for high level disinfection/cold sterilization) (7-17).

For the second stage of the study, quantitative testing of antimicrobial activity largely tests firs stage but also complements it as meaning that among substances with antimicrobial effect, Disinfectant Product no. 2 (according to Table 1, having the active substance on the basis of alcohols and with an indication of choice antiseptic action on hands) has the lowest antimicrobial potential, followed by Disinfectant Product no. 4 (according to Table 1, peracetic acid compound, recommended for high level disinfection/cold sterilization) while Disinfectant Product no. 5 (according to Table 1, quaternary compound based on ammonium salt with the indication of choice dental impression decontamination and instrument disinfection) and Disinfectant Product no. 6 (according to Table 1 , compound based on quaternary ammonium salts having the indication of choice for manual and rotary instrument decontamination and disinfection) destroyed all microbial strains tested. Disinfectant Product no. 7 (according to Table 1 , compound based on sodium hypochlorite having the indication of choice detergent-disinfectant of surfaces) and Disinfectant Product no. 1 (according to Table 1, compound based on alcohols with the indication of choice for decontamination and disinfection of surfaces) exhibit medium antimicrobial activity.

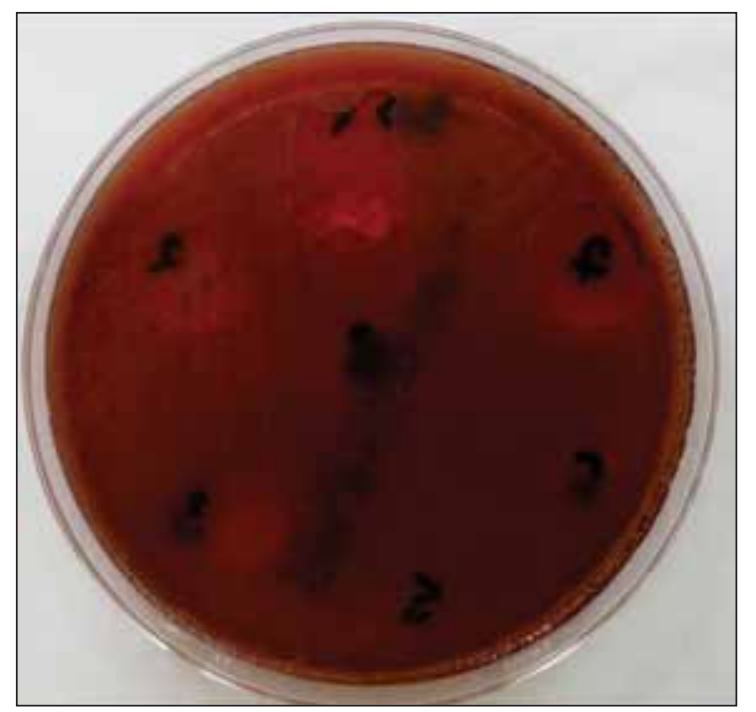

FIGURE 1. Highlighting the inhibitory activity of some substances with antimicrobial potential.

\section{CONCLUSIONS}

Following the results obtained, we were able to conclude on several aspects, we think very interesting, as follows: 
The infectious risk in implant-prosthetic rehabilitation, in classical dental prosthetics, as well as in orthodontics and dentofacial orthopedics, due to the non-decontamination of dental impressions, models, occlusion rims, wax patterns, and prosthetic restorations is real, is not invented, medical staff who manipulates these products (dentists, cabinet assistants, dental technicians) being exposed to infectious diseases, whether or not classified as professional illnesses.

Decontamination of dental impressions must also become a certainty in implant-prosthetic rehabilitation, in classical dental prosthetics and in orthodontics and dentofacial orthopedics, even though this work is disregarded and ignored by many practitioners (both those in the clinical compartment and those from the dental laboratory).

Most recommended desinfecting and/or sterilizing chemicals for the decontamination of dental impressions in implant-prosthetic rehabilitation, classical dental prosthetics as well as in orthodontics and dentofacial orthopedics would be indicated to have the active ingredient based on quaternary salts of ammonium, alcohols and/or halogenated compounds.

Always when the decontamination of dental impressions, models and/or prosthetic intermediate parts is carried out both in the implantprosthetic rehabilitation, but also in the classical dental prosthesis and orthodontics and dentofacial orthopedics, the user must wear appropriate protective equipment: mask, gloves and goggles.

Not always the manufacturers' recommendations in the package leaflet are in line with reality in practice.

\section{Acknowledgement}

In this article, all the authors have equal contributions.

\section{REFERNCES}

1. Burlibaşa M., Dumitru S.G., Tănase G., Sfarghiu L. Flora cavităţii bucale - element de contaminare directă şi indirectă în reabilitarea implanto-protetică. În: Progrese în medicina dentară, Vol. III, coordonatori: Trăistaru T., Burlibaşa M, lonescu I. Editura Ars Docendi, Bucureşti, 2012, pp. 48-63.

2. Burlibaşa M., lonescu I., Bodnar D. et al. Aspecte teoretice şi practice ale formării, dezvoltării şi combaterii biofilmelor microbiene în medicina dentară. Medicina Modernă. 2008, Vol. XV, Nr. 10, pp. 544-547.

3. Burlibaşa L., Burlibaşa M., lonescu I. Microflora cavităţii bucale - posibil factor de risc infecţios în practica stomatologică. Sibiul Medical. lanuarie-Martie 2003, Vol. XIV, Nr. 1, pp. 43-45.

4. Council on dental materials, instruments and equipment, Council on dental practice, Council on dental therapeutics. Infection control recomandation for the dental office and the dental laboratory. J Am Dent Assoc. 1996, 116: 241-248.

5. Council on scientific affairs and council on dental practice. Infection control reccomendation for the dental office and the dental laboratory. J Am Dent Assoc. 1996, 127: 672-680.

6. Missika P., Drouhet G. et al. Hygiene, Asespsie, Ergonomie. Un defi permanent. Editions CdP, Paris. 2001.
7. Burlibaşa M., Dumitru S.G., Tănase G., Sfarghiu L. Flora cavităţii bucale - element de contaminare directă şi indirectă în reabilitarea implanto-protetică. În: Progrese în medicina dentară, Vol. III, coordonatori: Teodor Trăistaru, Mihai Burlibaşa, lleana Ionescu. Editura Ars Docendi, Bucureşti, 2012, pp. 48-63.

8. Cristache C.M., Burlibaşa M., Tănase G. et al. Titanium as dental implant material. Metalurgia International 14, 2009, 14-16.

9. Şteţiu A.A., Oleksik M., Oleksik V. et al. Mechanical behavior of composite materials for dental obturations. Romanian Biotechnological Letters 18(4), 2013, 8528-8538.

10. Bodnar D.C., Pantea M., Bodnar T. et al. Patologia mucoasei orale la pacienţii vârstnici - studiu clinico-statistic. Acta Medica Transilvanica 2(2), 2012, 56-60.

11. Bodnar D.C., Dimova C., Bodnar T. et al. Dental management of patient with psychiatric disorders. Modern Medicine 17(10), 2010, 538-543.

12. Mocuţa D., Popovici L.R., Dumitriu A.S. et al. Life quality-condition of social welfare. Metalurgia International 14, 2009, 62-64.

13. Burlibaşa M., Burlibaşa L., Gavrilă L.B. et al. MicroRNA a macro Revolution in Medical Biotechnologies. Romanian Biotechnological Letters 13(6), 2008, 3977-3983.
14. Burlibasa M., Cernusca-Mitariu M., Cernusca-Mitariu S., Malita M. Theoretical and practical aspects related to biomaterials decontamination in dental medicine (with reference to dental prosthetics). Metalurgia International. Vol. XVIII, No. 4, 2013, pp. 261-267.

15. Tanase G., Burlibasa M., Muntianu L.A.S. et al. Testing the antibacterial potential of biomaterials in medical practice. Metalurgia International. Vol. XV, Spec Iss No. 2, 2010, pp. 160-162.

16. Burlibasa M., Muntianu L.A.S., Tanase G. et al. Study on microbial contamination of biomaterials in medical practice. Metalurgia International. Vol. XV, Spec. Issue No. 2, 2010, pp. 163-166.

17. Bilinschi L.G., Perieanu V.S.,

Perieanu M.V. et al. Isolation, identification and characterization of adhesion and development capacity of biofilms in microbial strains insulated in patients functionally rehabilited with fixed prosthetic restaurations. Acta Medica Transilvanica. Vol. 22, No. 4, 2017, pp. 97-100.

18. Bilinschi L.G., Perieanu V.S.,

Perieanu M.V. et al. Testing of microorganisms sensitivity to impression materials commonly used in dental prosthodontics. Acta Medica Transilvanica. Vol. 22, No. 4, 2017, pp. 110-112. 